\title{
The Circular Form in Ten Thousand Waves - A Cine-Installation Created by Isaac Julien
}

\author{
By Pablo Villavicencio*
}

\begin{abstract}
This paper is an analysis of the cine-installation, Ten Thousand Waves, by Isaac Julien, shown in Sao Paulo in 2012, which is composed of 9 contiguous screens that create a circular space of exposition through which the viewer moves. The mythical Chinese goddess Mazu is represented in the work crossing the screens constantly in conjunction with a narrative of the historic times of that country: Imperial, Modern and Contemporary. The viewer moves never having a whole vision of the work, because there are two screens in the center which contribute to a visual fragmentation. Julien builds up a simultaneous relation among the shots in the screens, where the cognitive effect of the montage, as in linking different shots, is transferred to the viewer. This montage procedure was named by Lev Manovich spatial montage; in this case, the temporality of the moving image is spaced in a circular form.
\end{abstract}

\section{The Sensory Experience}

At the moment I immersed myself into the space of the audio-visual artwork entitled Ten Thousand Waves, the dark room reminded me of the traditional cinema movie theater, but it was not at all like a conventional movie. Although it was shot on a 35 millimeter film, it was a great production revealing elegant and clearly cinematographic photography which was not very common in video art at least in the 60's up to the 90's. It was an audiovisual artwork that should be considered as a digital piece of updated expanded cinema, ${ }^{1}$ the 70 's theory by Gene Youngblood. The images were projected in 9 screens, distributed in the space in a lightly elliptical way, and two screens positioned in the center of the space. The light from the screens did not darken the environment completely. I could see the other viewers,

* PhD in Communication and Semiotics, University PUC-SP (Pontifícia Universidade Católica de São Paulo), Brasil.

1. The expanded cinema embraces a multidimensional and inter-media web, encompasses television, video and cinema, and is in the diverse expressions of audiovisual forms, for instance, the first computer films, multi-screens and projection environment, video art installations etc. It is a cinema that emerges from the fusion of esthetic sensibilities of the artists and from the technological innovation achieved in the audiovisual language. In these sensorial and synesthetic environments, the viewer is allowed the simultaneous perception of sensation and conceptualization (cognition). It is a cinema that seeks to expand the consciousness and the human capacity of communication (Gene Youngblood, Expanded Cinema (New York: P. Dutton \& Co., 1970). 
and their reactions, the majority sitting. Was it a vestige of traditional cinema apparatus ${ }^{2}$ that yet influenced us as a spectator?

However, in my second visit to the artwork, I chose to travel through the installation space between the screens/images/sounds with my body. I perceived the circular form of the audio-visual environment. Because there was a synch in between the screens that created an audio-visual sequence that produced spatial circularity throughout which I perceived the sounds that moved from one screen to another, at specific moments. The travelling of the sound through the space drew a circle. ${ }^{3}$ I asked myself if this circularity was a feature of an eastern culture. And this suggested to my body, passing through this circularity, a creation by the screen arrangement, moving also into the empty spaces and some blind spots, because there were pillars holding the architecture of the exhibition room. It interposed my view of some screens in certain angles. In other moments of the artwork, in looping, I preferred to stay sitting on wooden benches near some screens.

Was the existence of these benches another vestige of an apparatus of traditional cinema?

The simultaneous timing was evidently present in the construction of this artwork. It was impossible to see the whole movie at the same time. This was clear through my experience, although, I did not feel tired in creating my own trajectory, "creating my own films" in this cine-installation. ${ }^{4}$ But what was

2. The concept of apparatus occurs as a critical reflection about a dominant form of cinema by the theoretical approach of structuralism as Jean-Louis Baubry, Chritian Metz and Thierry Kuntzel in the 1970s. They point out a tendency, a situation imposed to the cinema viewer. The term apparatus characterizes the group of cinema operators - camera, moviola, projector - and the conditions of projection, as the dark movie theater, the concealed projector behind the immobilized viewer (André Parente, "A forma cinema: variações e rupturas" ("Shaped film: variations and breaks,") in Transcinemas (Org.), ed. Katia Maciel (Rio de Janeiro: Conta-Capa, 2009)).

3. The circle form is highly important in Chinese culture. In Taoism the circle is a symbol of emptiness, and is the base of the well-known Yin Yang symbol (Tom Bisio, Decoding the Dao, Nine Lessons on Daoist Meditation, accessed December 3, 2012, http://goo.gl/tpTr9u.

4. We utilized the cine-installation term created by Raymond Bellour, which according to this author "Already former, but very evident, from the turning point of 1999 and 2001 Venice Biennials, the installations developments (video and cinema) lead us to rethink the own cinema as installation in the long history of the apparatus of sound and image" (Raymond Bellour, "Cineinstalações" ("Cine Facilities,") in Cinema Sim, narrativas e projeções (Cinema Yes, narratives and projections), ed. Kátia Maciel (São Paulo: Itaú Cultural, 2008), 9). Roberto M. Cruz uses the term "filminstallation" (Roberto Moreira S. Cruz, Imagens Projetadas: Projeções audiovisuais e narrativas no contexto da arte contemporânea (Projected Images: audiovisual projections and narrative in the context of contemporary art) (PhD thesis, Pontifícia Universidade Católica, São Paulo, 2011), 10) we prefer to utilize "cine-installation" to 
moving my perception, plainly, was the crossing of the sound through the screens, and the character that represented a mythical, archaic spirit, called Mazu. ${ }^{5}$ In the artwork she emerged as a woman dressed in white, flying in different spaces, cities and fields, and times, Ancient Imperial, Modern and Contemporary China. She moved between the screens with lightness and grace like the characters of the film: Crouching Tiger, Hidden Dragon, Ang Lee, 2000.

An intriguing moment was when Chinese drums emerged and the screens, before entirely dark giving us a breathing space, now came up one by one following the sound of the drums. Until a strong beat arose and we saw, filled with images, all the screens, the chronologic timing of the beating of the drums seemed to blend with the simultaneous timing of the images, when the screens filled all at once, illuminating the space, and engulfing the viewer. What provoked us were a harmony and an epic sensation in a way present in the human spirit, a sensation that referred to a specific mythology of eastern culture that touched us. It seemed to me a humanity that, amid an exacerbated capitalism, needed to remind us of the ancient people, and their traditions and myths that diffused a more harmonious relation with nature.

According to André Parente, the circle is a symbol almost omnipresent in all cultures, "it is a symbol of universal harmony, that passes from the internal (self) to the outside (reality), from the micro (atoms) to macro (Earth, Moon, Sun, Cosmos)."6 The fact that the artwork was in a loop already indicated a circular temporality, because of the incessant repetition of the film. The artwork also indicated a relationship between man and nature, mainly in the images and sounds of ancient China, an epoch in which existence was strongly linked with the cycle of nature, and man related in a different way to time (in comparison with nowadays), linked to a slow, rural, natural and cyclic time. In this sense the work reminded us of the art of the consecrated video artist Bill Viola.

Moreover, the development of the narrative time in the work mixed an ancient past (almost a lost time), a past more recent (twentieth century), and a

avoid confusion of the word cinema with film (only made in pellicle). In Brazil we use film to refer to a work of traditional cinema and to refer to the pellicle of cinema.

5. According to the legend, she was born in 960 over Song Dynasty, the seventh daughter of Lim Yuan, on Meizhou island Fujian. There is a rich diversity of myths involving her and the ocean in which Mazu, using a red dress, guides the fishermen on the coast even during storms and harsh weather. One of the legends says that as a girl, she died of fatigue after swimming in the sea seeking her lost father; in the other version, that has a close relation to the film, she died climbing a mountain, when she was 28 years old, and flew to heaven and became a goddess. Mazu, despite her roots in Taoism, is recognized in both religions Buddhism and Taoism. The "goodness" was performed by the famous actress Maggie Cheung.

6. André Parente, Cinema em trânsito (Transit Film) (Rio de Janeiro: Beco do Azougue, 2011), 51. 
"present" (contemporary) time, and made us reflect about the development of historic epochs, and their presence in the collective memory and in the contemporary experiences of the inhabitants of China.

\section{Narrative and Formal Features}

We observed a blend of times in a narrative scope: a contemporary time, of quickness, immediacy in conflict with an older, archaic and slower time. Most of the audio-visual material was an unconventional fictional movie, with a montage made in a way for the viewer to link the shots whereby the space-time continuity which was incorporated in our perception of the cinema and television narrative. There was also documentary data that referred to other historic times from the political history of China. These sequences showed the Communist revolution and were combined in a few moments with the fictional sequences (one gradually was replaced by another in the screens).

We were immersed in a space that suggested a circular form, perceiving a dominant simultaneous time, different narrative and diegetic times, but with a slowness prevailing in the duration of the shots. There were some sequence

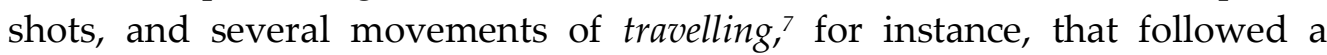
character of a woman in a tram. But in most of the shots the camera was static and the objects and the "real" or fictional characters (there was a stage) were in movement.

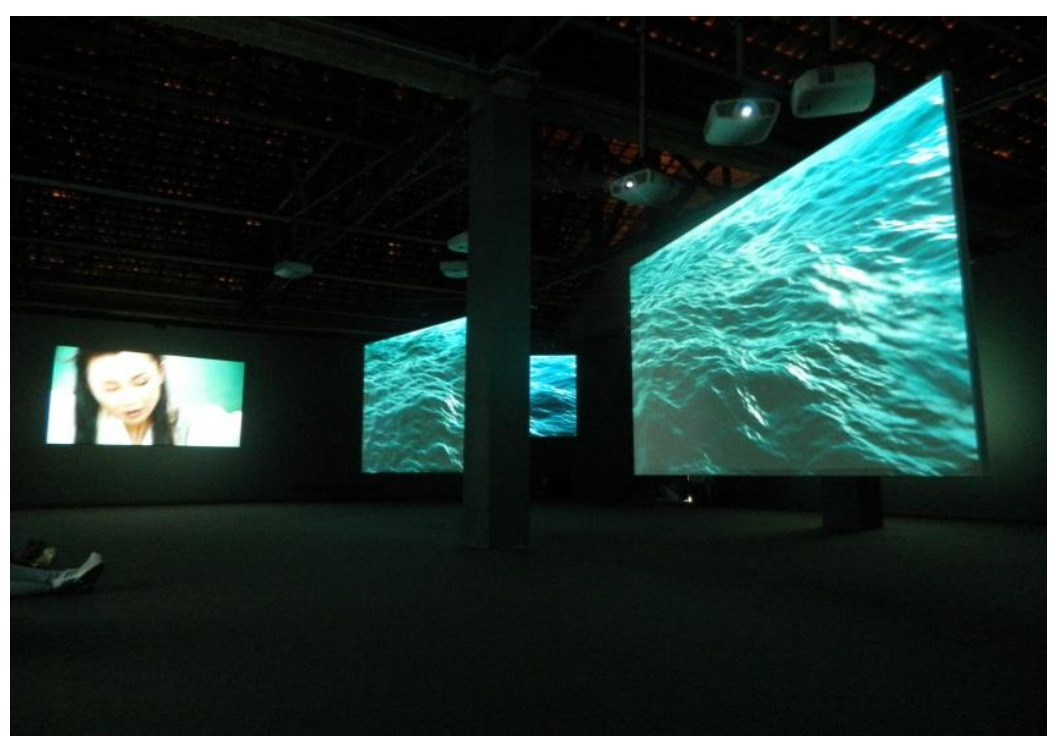

Image 1. Screens of Ten Thousand Waves, by Isaac Julien

\footnotetext{
7. Camera's movement: in which she leaves her axis and dispenses the fixity of tripod.
} 
The montage was achieved in two ways: there was one in each screen, within the shots and the main spatial montage, in which the shots were articulated in relation to the images of the contiguous screens. The filmmaker concentrated on his construction of these relations. Lev Manovich, defined his concept of spatial montage, sustaining that the artist must build logic to determine what image appears in a certain moment as well as the type of relation between them. ${ }^{8}$

As shown in Image 1, we saw Mazu in a medium shot, she moved gracefully and looked down. Initially, this shot was repeated in most of the screens, and then, the shots of the sea emerged in slow motion, filling almost all the screens except one in which the image of $M a z u^{9}$ remained, and she looked down. The artwork was based on a disaster in 2004, when 21 illegal immigrants (cockle pickers) were drowned in Morecambe bay, ${ }^{10}$ England. The screens are arranged in the exhibition space one beside the other, therefore, we can link the shots (the images) and deduce that she looked to the sea, as her expression seemed to search for the corpses of the Chinese laborers drowned in this tragedy.

Therefore, Roberto Cruz ${ }^{11}$ quoting the concept of Manovich, pointed out that in the spatial montage, we make a cognitive operation of the (re)montage of the order of sequences, but, in this case, there was a (re)montage of the shots. Thereby, the narrative elements of traditional cinema were used in the background of a cine-installation, in a new expanded cinema. In this case the film technique match cut was used, more specifically, an eyeline matching (or a look raccord, ${ }^{12}$ a montage operation), that suggested a linking, a continuity between the shots of Mazu and the sea, but these shots emerged simultaneously not in the succession of a classical narrative film. In this sequence we heard a voice over ${ }^{13}$ of the poetess Wang Ping ${ }^{14}$ performing her poem that originated in the name of the film and inspired this cine-installation.

8. Lev Manovich, The Language of New Media (Massachusetts Institute of Technology, Massachusetts: MIT, 2001), 322.

9. Mazu, goodness of waters, is equivalent to Yemanjá, the goodness in African culture in Brazil.

10. The tragic event was known as the Morecambe Bay cockle pickers' disaster, http://goo.gl/OAqtsO.

11. Cruz, "Imagens Projetadas: Projeções audiovisuais, 59.

12. Raccord is a French term for a variety of montage operations aiming to obtain a space temporal continuity between the shots. This allows for the linearity of film sequences.

13. This is a cinema and video term that refers to a voice from a narrator, a person that does not appear in the film, common in the classic documentary.

14. The name Ten Thousand Waves is from a poem and a book of Wang Ping, based on the Morecambe tragedy. Julien commissioned Ping to write a script for his film Small Boat, about global immigration, but when he had read the poem finished, 


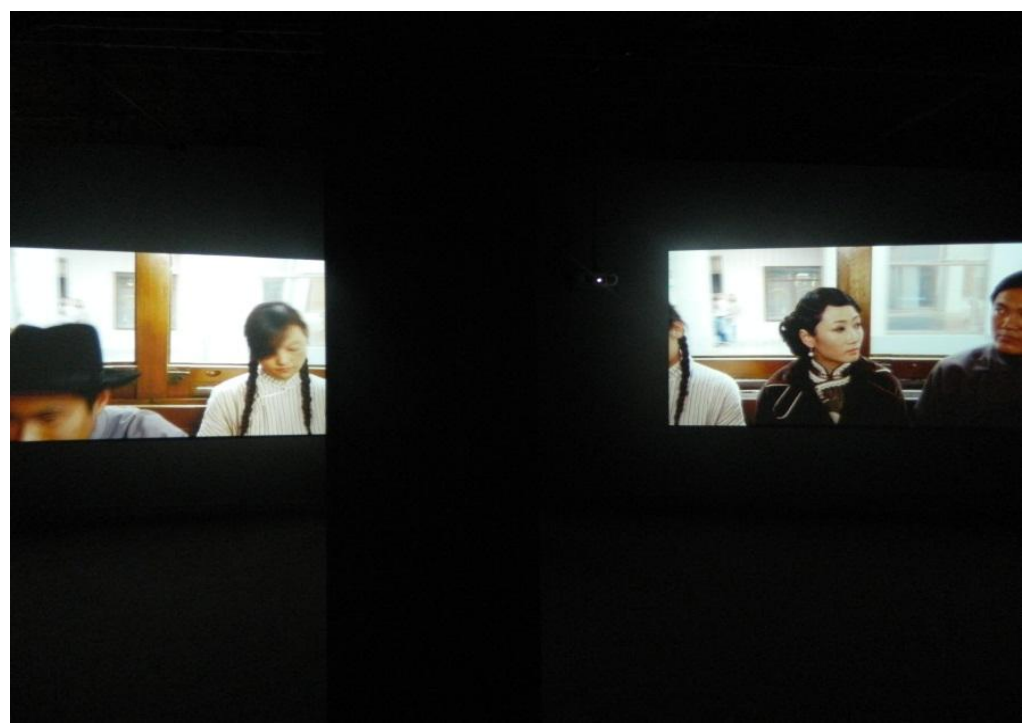

Image 2. The Space Inside the Tram

The Image 2 exemplifies the construction of images space: the space shown in a shot (in the interior of one screen) resembles unfolding to another screen (shot), as if the work created continuity between the space into different screens. There was another woman character that moved through different cities along different historic times. Due to her clothes, she seemed to be the same character of a Chinese film entitled Shen Nu (The Goodness, by Yonggang $\mathrm{Nu}$, 1934). As Mark Nash also observed in his paper about the artwork, called Electric Shadows, there were narrative fragments in this film. ${ }^{15}$ And while the scene occurred in a tram, the costumes of the characters in this part of the film seemed to represent the early twentieth century. In this sequence, several shots explored the tram space; probably they had been shot simultaneously with more than one camera. The woman observed the city and walked through the tram, she moved "from one screen to another," at one moment, she "crossed three screens" until she arrived at the back of the vehicle. The spatial contiguity of the shots in the screens contributed to the immersion of the viewer, we had the sensation of being in the tram. In some screens we could observe the movement of the vehicle, mainly in the shots from the back of the train (movement of travelling out) and in the forefront (travelling in). Suddenly, in this sequence, the shots of travelling taken from the side windows began to alternate (in the montage) with documentary shots in black and white (some in movement, others static) recording ordinary people, some on bicycles, with families, traders other people etc. It

he was inspired to create the cinema installation. The book has many memories from China as Ping was born in China and immigrated to the USA in 1986.

15. Mark Nash, "Sombras Elétricas" ("Electric shadows,") Geopoéticas: Isaac Julien (São Paulo: Sesc, 2012), 63. 
was a record which seemed to be from almost the same period of the fictional shots in the tram, therefore the narrative historic time practically coincided with the epoch that was recorded in the shots of the documentary. A possible transparence of the montage was broken by a discontinuity between the documentary and fictional images. The tram transported the characters and the viewer for a ride through the historic times of China, through the fictional representation as well as the documentary, and the viewer's body moving through the installation space.

Each screen shot of the same scene was presented at different angles, and some shots were repeated in almost all screens except for the two central screens. After an interval, new shots emerged, and they were images of a contemporary city: Beijing, where we saw several cars traversing from one screen to another drawing a circular movement around the viewer, while people in the film passed over from one screen to the other. New colorful documentary images appeared among the current time images, showing scenes of an official military parade of the Communist Chinese party, where we could see two posters side by side in a shot, like two windows inside the screens, one showed Mao Tse Tung, and on the other Stalin, two dictators in the same shot. The juxtaposition of these two images in a shot, and the relation between the screens, brought to mind the concept of vertical montage ${ }^{16}$, where the shots operated like screens, in simultaneity, like in the video editing, blending shots that would be shown in a parallel montage in traditional cinema.

Mazu appeared and "crossed" the screens at several moments performing low-flights, cutting the frame vertically (in these passages her image was not repeated) and moved in the direction of outside the boundaries of the screens $^{17}$ (out of the image field). We saw several shots of the same window inside a contemporary building and suddenly she appeared in a shot and observed the other characters and "the viewer" (looking to the camera). All screens contained a shot of the top of the building at night. Maybe this scene had a reference in the film: Empire (1963), by Andy Warhol that lasted 24 hours, and was presented as a cine-installation too. Making a comparison

16. The concept of vertical montage was created by Sergei Eisenstein and this idea was developed by Philippe Dubois to distinguish a video-graphic montage (remixing) of a cinema montage. According to him: In fact, everything happens as if the horizontal relations of a cinematography montage (the string of shot to shot, the rule of successiveness, the syntagmatic dimension) would accumulate "vertically" under the image paradigm itself (where we have the "the image composition" and "the image thickness") (Philippe Dubois, Cinema, Vídeo, Godard (São Paulo: Cosac Naify, 2004), 89).

17. Beyond the field of the image (framed space, visible, where the characters, scene objects and scenery are) called out of field too, it is invisible and plays with the imaginary of the viewer. 
between the Image 3/4 of Warhol's film and Image 2 of the Julien's installation, we concluded that the angle of the shots and the buildings were very similar. All of which emphasized the current economic boom of China, now a capitalist empire, but still communist politically.

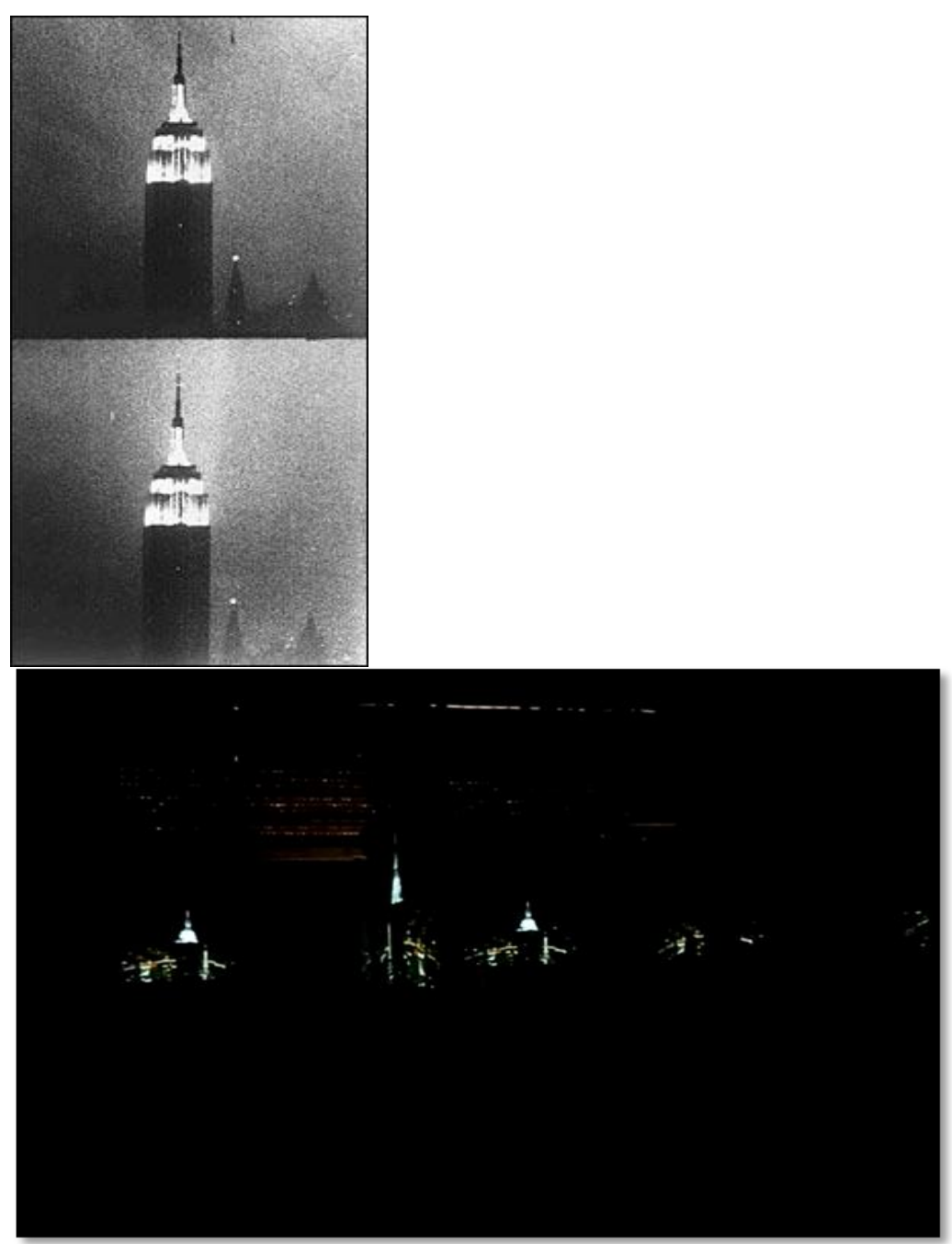

Image 3 and 4. A Shot of the Film Empire (1963), by Andy Warhol, and one of Ten Thousand Waves

After another break with dark screens and a brief silence, nocturnal shots emerged of the city. A man carrying a small cart loaded down passed from side to side, from one screen to another; the tram made the same movement and "traversed" the screens too. The movement of the objects and characters in the shots, once again created a circularity surrounding the viewer. The spaces between the screens (outside the frames) were filled with our imagination, for example, we "kept going" with the image of the tram in movement, thereby we expanded the space of the screens with the film imaginary. 


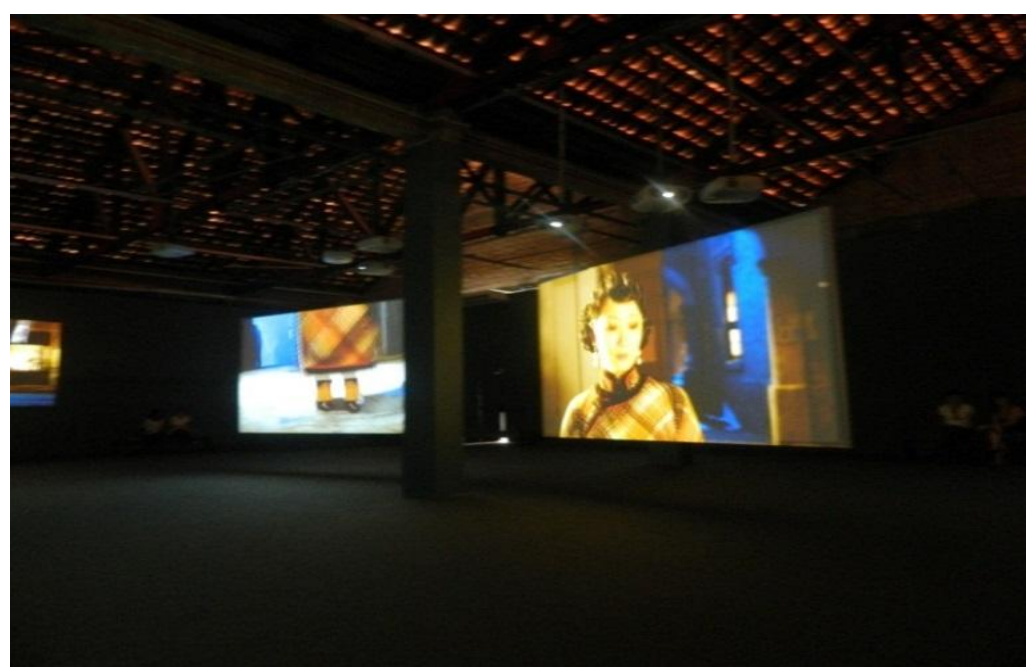

Image 5. Ten Thousand Waves, the "body framed"

The woman that walked in the city from the early twentieth century reappeared, and she was shown in more than one screen (in a middle shot), but in lightly distinctive times, as we can see in the Image 5. For instance, in one shot she smoked a cigarette in another (simultaneously) she had not started smoking. There were also shots in reverse of her walking. At first she walked and faced the camera, in the other she was walking backwards. Her body was indented by the framings, for example: a middle shot of the woman on a screen and a shot of her feet in another. Conforming to the codes of traditional cinema, we "(re)arranged her body image" linking the shots, using our imagination. In this sequence, blue was the dominant color, creating a sensory environment, engulfing ${ }^{18}$ the bodies of the viewers in spaces of color (there were other colors: red and green), creating colorful atmospheres in each sequence. This was remarkable because the viewers could walk, drift in the space of the installation. At this moment emerged a parallel montage, but with simultaneity rather than successiveness, from images of representing the early twentieth century city and the contemporary city.

The contemporary city appeared and the woman now met a man inside a huge building. A kind of suspense was created before the meeting, through travelling, one from left to right, and another from the opposite way, each following a character, we then observed the immediacy of the meeting. Such

18. Claire Bishop includes one work of Isaac Julien in one of her conceptions about installation art: mimetic engulfment. In the same line as the paper "Leaving the Movie Theatre" by Roland Barthes, she stated: "Works like Isaac Julien's threechannel installation Baltimore 2003 makes manifest the psychological and physical split that Barthes describes: we are enticed by the smooth play of images across the screens, but also by the intense blue walls that surround them" (Claire Bishop, Installation Art: a Critical History (London: Tate Publishing, 2014), 96). In our view, this split occurs more in the traditional cinema than in the artwork of our study. 
shots, at certain times, got closer to the scenery structure (the building walls), which provoked a sense of tactility under the cold texture. We could imagine that the exhibition space, created for the screens, reinforced the haptic senses. The viewer could attach another spatial dimension for the images, though they were two dimensional, the third dimension could be strongly imagined. And the experience in this environment could be paralleled to an observer in an exhibition of sculptures, due to the filling of the space with colors of the screens and some images that can awake the viewers' haptic sense. In the meeting the characters kept silent, sitting around a table and behind them we saw a red painting. These shots were repeated in almost all the screens and gradually were being replaced with documentary shots of a military communist parade on the streets, where the predominant color was red. The color indicated some continuity between these different shots, combining historical archives with a "fictional film" in an unusual way. This sequence alluded to the contradictions of a country in which a strong capitalism developed at the same time of a totalitarian, oppressive communist regime.

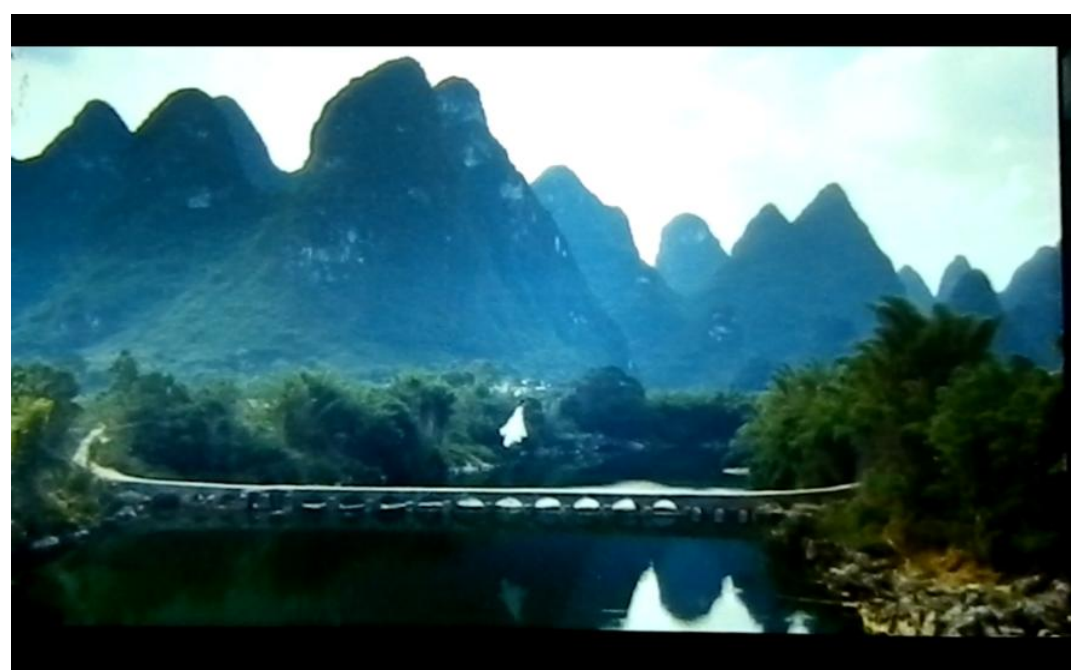

Image 6. Mazu Flying Over the Ancient Forest

The Chinese drums sounded hard and in all the screens faded in aquatic shots, and at this time the dominant color was green. We saw a man submersed in the water, drowned. A lot of shots were shown and disappeared in sync with the drums sounds. Mazu reappeared in a close up and, shot by shot, she occupied almost all the screens, whereas less in the central screens in which we saw frontal photographs of a man and his clothes, and then we understood that he was a cockle picker who had died. In the central screens, in the middle of the exhibition space, then we saw an ancient sailboat amid a representation of the old, ancient China, probably where the legend of Mazu came from. The sailboat contained a group of characters, maybe fishermen, and in the surrounding screens several trees were shown; 
the viewer was encircled by a forest environment. The men got out of the boat, and came onto the land. Landscapes of mountains and an ancient temple emerged, we saw forest reflections, and their own reflections in the water when they were crossing a bridge. The landscapes and the panoramic views were predominant in this sequence, as the flying of Mazu over the forest that we can see in the Image 6. As reported by Mark Nash, the artwork referred to the landscape painting of Imperial China, that was rich in detail, and in which a totality of the image must be imagined rather than demonstrated. ${ }^{19}$ And the installation form of art was a proper medium to do this.

When Mazu looked down, again the procedure of eyeline matching was used, linking the shots of her gaze and the shots of the men in the forest, as she observed them. One man, in one of the screens, seemed to perceive her presence. There was a long sequence that took us to the interior of a mythic, archaic, slow narrative, and a feeling of transcendence, linked to the unconscious mind. Not only because in some shots the men were shown sleeping, but by the sensation of a suspended, slower time. There was an overlapping of two shots: one was a close up of Mazu, the other was one of the trees in the wind. These shots spread to several screens. The movements of the camera around the trees made it spin in the frames. One more time the circle became a reference. In our experience this was the strongest sequence, corresponding to the climax of the cinema installation, in which the drums and the singing of a woman had a great impact. We could feel a kind of "spiritual ecstasy," created by the sounds of the drums and by the sensory spatial engulfment of a forest, and for a moment of time, dense and slow.

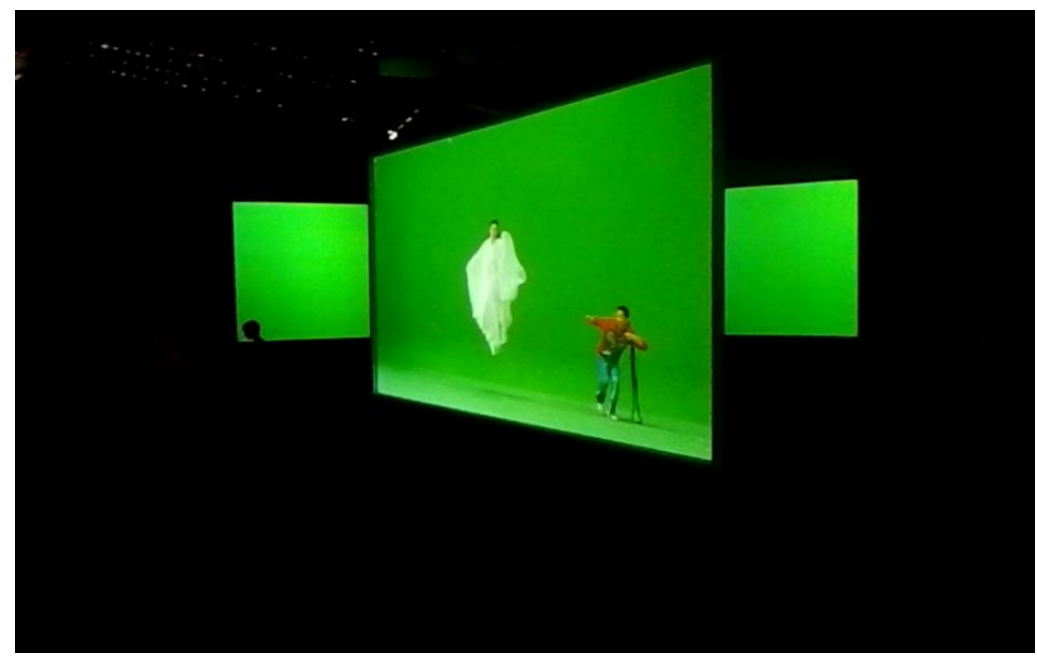

Image 7. The Apparatus is Unveiled (digital chromakey)

19. Nash, "Sombras Elétricas." 
Near the end of our experience with the artwork, the several screens started showing the film construction (making of), we saw the film team. They unveiled the process of filming the flight of Mazu, showing the green background of chromakey, with the actress rehearsing her movements with help from technicians and a ventilator that imitated wind to detach her "flight", shown in the central screen of the Image 7. This apparatus revelation provoked a rupture with the concept created by André Bazin: "the reality impression" that is common in the traditional cinema, and therefore, the installation gained a tone of meta-language and self-reflexivity, disrupting any transparent montage. This meta-language scene gradually dissolved the transcendence feeling enclosed in the previous sequence. Our experience of this fantastic work arrived at its end.

\section{Conclusion}

Therefore, Ten Thousand Waves created an audio-visual atmosphere surrounding the viewer, which can traverse the color spaces that emanate of the screens, never seeing the whole images and sounds. Julien worked with the spatial montage, depurating the simultaneity of the shots and provoking cognitions that intended a viewer montage. In certain sequences the installation became a slow cinema, the sensation of a suspended time was suggested, because this kind of time maybe arouse an unconscious feeling that brought to mind an ancient humanity, in this case the Chinese Imperial epoch. And the meta-language sequence unveiled the creative process of the work, and gave time to our reflections. The circular spatial configuration of the work is similar to the panoramas of the nineteenth century, but they have only the objective of reinforcing an immersion. In Juliens work the circle has strong cultural and religious meanings that are important for the east culture. The sound and screen images in certain moments of our experience clearly designed the circular form in space and in our minds.

\section{Bibliography}

Bellour Raymond. "Cineinstalações" ("Cine Facilities.") In Cinema Sim, narrativas e projeções (Cinema Yes, narratives and projections), Edited by Kátia Maciel. São Paulo: Itaú Cultural, 2008.

Bishop Claire. Installation Art: A Critical History. London: Tate Publishing, 2014. 
Bisio Tom. Decoding the Dao, Nine Lessons on Daoist Meditation. Accessed December 3, 2012. http://goo.gl/tpTr9u.

Cruz Roberto Moreira S. Imagens Projetadas: Projeções audiovisuais e narrativas no contexto da arte contemporânea (Projected Images: audiovisual projections and narrative in the context of contemporary art). PhD thesis, Pontifícia Universidade Católica, São Paulo, 2011.

Dubois Philippe. Cinema, Vídeo, Godard. São Paulo: Cosac Naify, 2004.

Manovich Lev. The Language of New Media. Massachusetts Institute of Technology, Massachusetts: MIT, 2001.

Nash Mark. "Sombras Elétricas" ("Electric shadows,") Geopoéticas: Isaac Julien. São Paulo: Sesc, 2012.

Parente André. Cinema em trânsito (Transit Film). Rio de Janeiro: Beco do Azougue, 2011.

__. "A forma cinema: variações e rupturas" ("Shaped film: variations and breaks.") In Transcinemas (Org.), Edited by Katia Maciel. Rio de Janeiro: Conta-Capa, 2009.

Youngblood Gene. Expanded Cinema. New York: P. Dutton \& Co., 1970. 
